\title{
Spray dried plasma as an alternative to antibiotics in piglet feeds, mode of action and biosafety
}

\author{
Anna Pérez-Bosque ${ }^{1}$, Javier Polo ${ }^{2}$ and David Torrallardona ${ }^{3^{*}}$
}

\begin{abstract}
The use of growth promoting and therapeutic antibiotics in piglet feed has been a concerning subject over the last few decades because of the risk of generating antimicrobial resistance that could be transferred to humans. As a result, many products have been proposed as potential alternatives to the use of antibiotics, and among these, spray dried plasma is considered one of the most promising. However, there have been concerns about its biosafety, particularly during periods of emergence or re-emergence of swine diseases in different regions of the world, such as the recent porcine epidemic diarrhea virus outbreak in North America. The objectives of this paper are to review recent publications about the use of spray dried plasma as an alternative to antibiotics in weaned pig diets, the possible mechanisms of action of spray dried plasma, and the existing evidence related to the biosafety of spray dried animal plasma. Particular attention is given to studies in which spray dried plasma has been directly compared to antibiotics or other alternative antimicrobial products. Several studies on the possible modes of action for spray dried plasma, such as preservation of gut barrier function or modulation of the immune response, are also reviewed. Finally, the paper focuses on the review of the existing studies on the risks of disease transmission with the use of spray dried plasma from porcine origin. Overall, spray dried plasma is a promising alternative to in-feed antimicrobials for piglets, particularly during the early stages of the post-weaning phase. Additionally, there is enough evidence to support that commercial spray dried porcine plasma is a safe product for pigs.
\end{abstract}

Keywords: Antibiotics, Antibiotic replacement, Biosafety, Gut barrier function, Immunomodulation, Piglets, Spray dried plasma, Spray dried porcine plasma

\section{Background}

Spray dried plasma (SDP) is a protein rich product obtained from the industrial fractionation of blood from healthy animals. Blood is collected with an anticoagulant and centrifuged to separate the blood cells. Plasma is then concentrated and spray-dried under high pressure to achieve a minimum of $80{ }^{\circ} \mathrm{C}$ throughout its substance (Fig. 1). With this procedure, proteins preserve most of their biological activity $[1,2]$.

Since SDP was first proposed as a protein source for use in pig diets in the late 1980s [3, 4] many studies have demonstrated an improvement in piglet performance with its use. Inclusion levels of 4-8 \% are recommended

\footnotetext{
* Correspondence: david.torrallardona@irta.cat

${ }^{3}$ IRTA, Animal Nutrition and Welfare, Mas de Bover, Ctra. Reus-El Morell, km.

3.8, E-43120 Constantí, Tarragona, Spain

Full list of author information is available at the end of the article
}

for optimal results [5-7]. Several studies have also reported that SDP reduces the incidence of post-weaning diarrhea [8-10]. A greater efficacy of SDP has been described in younger pigs which have a less mature immune system compared to older pigs fed the same diet [11], or in pigs kept under less sanitary conditions [12]. Based on these observations, the hypothesis for a protective effect of SDP by supporting the immune system or by acting directly against pathogens has gained support $[12,13]$.

The immunoglobulin-rich fraction in plasma has been suggested to be responsible for the beneficial effects of SDP [14]. Although newborn piglets have the capacity to absorb immunoglobulins from colostrum, this ability is lost very soon after birth, and for most of the lactation period, IgA and other immunoglobulins in milk cannot be absorbed from the gut lumen. Their presence in the 


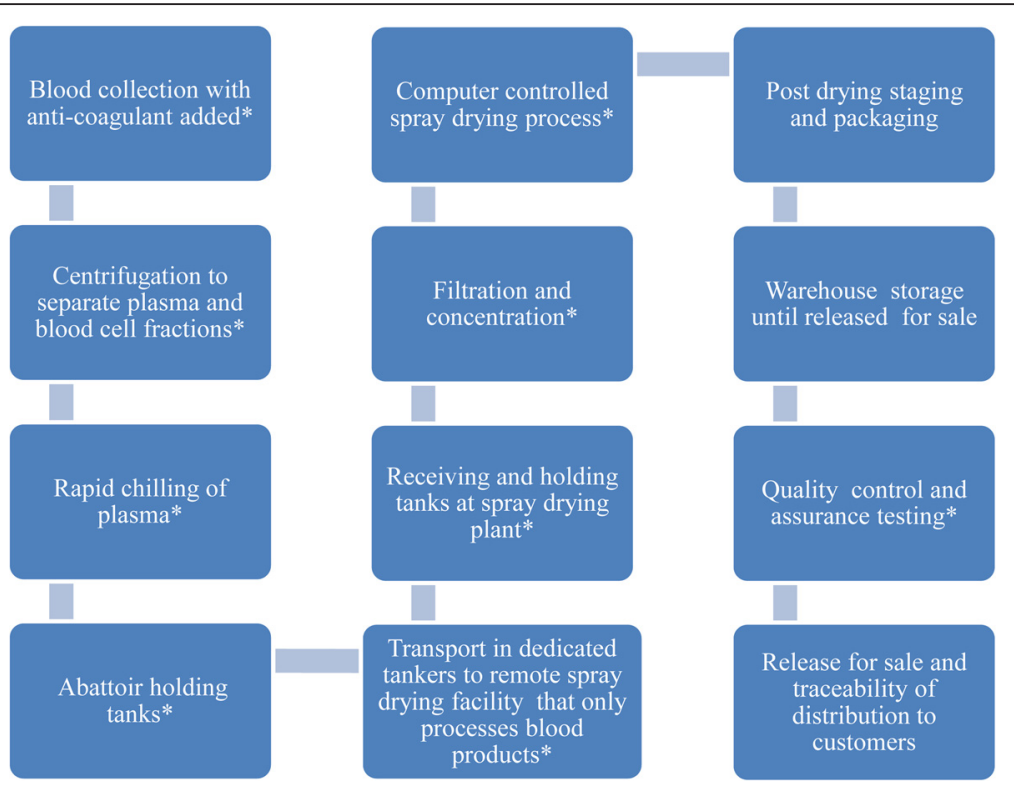

Fig. 1 Schematic overview of general steps involved in the industrial production of spray-dried plasma. Critical control points for quality assurance and quality control. Manufacturers following good manufacturing practices collect blood from animals inspected and determined fit for slaughter for human consumption. Blood flows into an enclosed system, separated into plasma and blood cell fractions, rapidly chilled to $4{ }^{\circ} \mathrm{C}$ and held in insulated holding tanks. Then plasma is transported in cleaned, sealed dedicated tankers to a remote spray drying facility where it is held in insulated tanks. Alternatively, the whole blood is chilled to $4{ }^{\circ} \mathrm{C}$ in the slaughterhouse and transported to remote spray drying facility where it is split into plasma and blood cells fractions. At abattoirs, collection systems and holding tanks are cleaned and sanitized by standard operating procedures specific for each plant. Holding tanks at abattoirs or spray drying plants are cleaned and sanitized when emptied. Filtration and concentration systems are cleaned per standard operating procedures. Standard operating procedures are in place for continual monitoring and recording of computer controlled spray drying process. Each lot of spray dried product is identified at packaging and must pass quality control and assurance testing before release for sale. Product lot number allows traceability of distribution to customers

lumen is thought to contribute to the defense against infectious organisms to which the sow is resistant by assisting the piglet's innate immune response (e.g. by neutralizing toxins or by the opsonization of pathogens) [15]. However, under modern commercial conditions, piglets are usually weaned well before their ability to produce their own IgA is developed at around 6-8 weeks of age [16]. For this reason, the addition of immunoglobulins in the post-weaning diets for pigs up to 8 weeks of age may be advantageous. Many of the bioactive components in milk (including immunoglobulins, hormones and growth factors) originate from blood, cross the mammary epithelium, and are secreted intact into the milk $[17,18]$. Therefore, it should be expected that many of the immunoglobulins, growth factors, bioactive peptides, and other biological components in milk may also be present in SDP.

Because of the increasing concern regarding the use of antibiotics in piglet feeds due to the risk of generating antimicrobial resistance that can be transferred to humans, intensive research has been conducted to find alternatives to both growth promoting and therapeutic antibiotics. Among the many products studied, SDP has been proposed as one of the most effective alternatives [7, 19]. However, the recent emergence of porcine epidemic diarrhea virus in North America raised concerns about the risk of disease transmission with the use of spray dried plasma from porcine origin (SDPP) in feed for pigs. The objectives of this review are to update the evidence supporting SDP as an alternative to antibiotics in diets for weaned pigs, to discuss recent studies about the possible modes of action through which it functions, and thoroughly review studies assessing the risks of disease transmission with the use of SDPP in feed.

\section{Review \\ Efficacy of spray dried plasma and evidence supporting its use as an alternative to antibiotics}

The absence of SDP in the first nursery feed has been identified as a highly significant risk factor for mortality in nursery piglets in commercial swine operations [20]. The improvements obtained in feed efficiency with the use of SDP are much more evident in piglets with a poorer health status [7], which is likely a reflection of the energy and nutrients expended to generate an immune response. Indeed, some authors have reported significant interactions between SDP and the environment on piglet performance. Thus, greater performance enhancement by SDP has been reported in piglets reared under a conventional environment compared with a clean environment (i.e. new experimental facilities) [12]. 
A similar interaction has also been reported for antibiotics, as they have little or no effect on performance when the animals are kept under clean conditions compared with an environment with poor sanitation [21], supporting the idea that both antibiotics and SDP may have a health promoting effect.

Most studies that evaluated dietary SDP in the presence or absence of dietary antibiotics have not found an interaction between the two products, suggesting that the effects of SDP and antibiotics may be additive $[11,12,22,23]$. This may be explained by differences in the effectiveness of SDP and antibiotics against different pathogens. For example, in contrast to antibiotics, SDP may also be effective against viruses and toxins [24-27]. Feeding pigs with 1-2.5\% SDP during the initial weeks of the growing phase, in a farm with a high prevalence of disease associated with porcine circovirus (PCV2-SD), reduced cumulative mortality over the entire growing-finishing period from 12 to $6 \%$ along with a five-fold reduction in medication costs per pig, even though diets contained antibiotics [24]. Additionally, it has been reported that the inclusion of SDP is effective for counteracting the negative effects of dexonivalenol (a mycotoxin produced by Fusarium fungi) on the feed intake and weight gain of nursery pigs [26]. In the same study, SDP was reported to be more effective than a clay binder. Recently, another study has reported that SDP, fed during the first 12 days post-weaning, mitigated the negative effects of feeding a diet containing multiple mycotoxins during the subsequent 3 weeks [27]. Finally, although some trials suggest tendencies or significant interactions between SDP and antimicrobials $[28,29]$, it can be hypothesized that, under the conditions of these particular studies, both types of products may have been equally effective against the specific pathogens present.

Many studies (see summary in Table 1) have shown that piglets fed SDP perform equally well or better than piglets fed antibiotics [11, 12, 23, 28-32], or other alternative products such as organic acids [30, 33], other sources of immunoglobulins [33-36], plant extracts [37], zinc oxide [33], copper sulfate [38], or carbadox [33]. In a recent study conducted under field conditions [32], the use of medicated feeds (colistin, lincomycin and spectinomycin for the first week followed by colistin and chlortetracycline during weeks 2 and 3) has been compared to the use of non-medicated feeds containing SDP (5\% for the first week and $3 \%$ during weeks 2 and 3). Similar effects on performance were observed with both approaches, although it appeared that the effect of SDP was more effective during the first week of the trial, whereas the effect antibiotics was superior during the second and third weeks. Other studies comparing SDP with antibiotics also suggest that while the effect of SDP was larger during the first weeks post-weaning, the effect of antibiotics persists for a longer period of time [29,39].

Several authors have compared SDP to antibiotics and other alternative antimicrobial products under conditions of experimental challenge with pathogenic organisms. A comparison between SDP and colistin in piglets experimentally challenged with $E$. coli $\mathrm{K} 99$ [28], revealed positive effects on performance for both products, relative to a challenged control. However, while SDP resulted in an increased number of lactobacilli in the ileum and cecum, colistin reduced $E$. coli in the ileum and cecum and enterococci in the cecum. Similarly, in another study with $E$. coli $\mathrm{K} 99$ challenged piglets, SDP improved performance relative to a control diet, calcium formate had no effect, and colistin had an intermediate effect [30]. In piglets experimentally challenged with $E$. coli $\mathrm{K} 88$, SDP has been shown to have similar efficacy to an egg yolk preparation with specific antibodies against the challenging agent [35]. Both products improved performance, preserved the integrity of the gut mucosa, reduced scours, E. coli K88 shedding and mortality. In another trial by the same group under similar conditions [35], SDP and egg yolk antibodies were compared to zinc oxide, fumaric acid and carbadox, and all the products reduced scours and mortality while improving the integrity of the gut mucosa. Finally, a comparison between SDP and a combination of colistin and amoxycycline using piglets challenged with E. coli K88 [23], showed that while both products reduced the concentration of specific E. coli K88 IgA, only SDP reduced intestinal inflammation by down-regulating cytokine expression.

\section{Mode of action of spray dried animal plasma}

Maintenance of gut barrier function is critical for normal nutrient absorption while excluding toxins and microorganisms [40]. Mucosal permeability depends mainly on the capacity of tight junctions to efficiently seal the apical poles of epithelial cells. The permeability of the intestinal epithelium is regulated by several stimuli and its increase is associated with secretory diarrhea [41]. Proinflammatory cytokines, such as IFN- $\gamma$ and TNF- $\alpha$, increase epithelial permeability by reducing the expression of tight junction proteins [42, 43]. Moreover, an impaired intestinal barrier function contributes to disease pathogenesis especially when luminal antigens challenge the intestine.

Several studies performed with SDP have shown positive effects on the intestinal barrier. For example, oral supplementation of piglets with SDP ameliorated rotavirusinduced diarrhea [44] and reduced the severity of disease in calves exposed to coronavirus [45]. In rats with intestinal inflammation induced by Staphylococcus enterotoxin B (SEB), SDP attenuated the toxin effects on intestinal permeability as well as on tight junction protein expression 
Table 1 Studies comparing spray dried plasma (SDP) to antibiotics or other alternative substances

\begin{tabular}{|c|c|c|c|c|c|c|}
\hline $\begin{array}{l}\text { Age of piglets } \\
\text { (days) }\end{array}$ & Challenge & $\begin{array}{l}\text { SDP dose } \\
(\mathrm{g} / \mathrm{kg})\end{array}$ & $\begin{array}{l}\text { Observations for } \\
\text { SDP vs. Control }\end{array}$ & $\begin{array}{l}\text { Reference Product(s) } \\
\text { and dose }(\mathrm{g} / \mathrm{kg})\end{array}$ & $\begin{array}{l}\text { Observations for SDP vs. } \\
\text { Reference Product }\end{array}$ & Reference \\
\hline \multirow[t]{2}{*}{21} & \multirow{2}{*}{$\begin{array}{l}\text { Uncleaned } \\
\text { nursery }\end{array}$} & 30 & No differences observed & \multirow[t]{2}{*}{ Egg yolk antibodies (2) } & No differences observed & \multirow[t]{2}{*}[36]{} \\
\hline & & 60 & $\uparrow$ Weight gain & & $\uparrow$ Weight gain & \\
\hline 21 & None & 50 & $\uparrow$ Weight gain; $\uparrow$ Gain:Feed ratio & $\begin{array}{l}\text { Colistin }(0.12)+ \\
\text { Lincomycin }(0.044)+ \\
\text { Spectinomycin }(0.044)\end{array}$ & No differences observed & {$[32]$} \\
\hline 18 & None & 60 & $\uparrow$ Weight gain; $\uparrow F e e d$ intake & Copper sulfate (0.2) & No differences observed & {$[38]$} \\
\hline \multirow[t]{2}{*}{21} & \multirow[t]{2}{*}{ E. coli K99 } & \multirow[t]{2}{*}{60} & \multirow[t]{2}{*}{$\uparrow$ Weight Gain } & Colistin (0.3) & No differences observed & \multirow[t]{2}{*}[30]{} \\
\hline & & & & Calcium formate (18) & $\uparrow$ Weight gain; $\uparrow F e e d ~ i n t a k e$ & \\
\hline \multirow[t]{2}{*}{21} & \multirow[t]{2}{*}{ E. coli K99 } & \multirow[t]{2}{*}{60} & \multirow[t]{2}{*}{ No differences observed } & Colistin (0.3) & $\uparrow$ Villi height; $\uparrow E$. coli & \multirow[t]{2}{*}[30]{} \\
\hline & & & & Calcium formate (18) & $\uparrow$ Villi height & \\
\hline 20 & None & 60 & $\begin{array}{l}\uparrow \text { Gain:Feed ratio; } \downarrow \text { Monocytes; } \\
\downarrow \text { Macrophages in Peyer's patches; } \\
\downarrow \text { Macrophages, B Lymphocytes and } \\
\gamma \delta+T \text { cells in lymph nodes; } \\
\downarrow L y m p h o c y t e \text { and cell density in } \\
\text { lamina propria }\end{array}$ & $\begin{array}{l}\text { Carvacrol }(0.015)+ \\
\text { Cinnamaldehyde } \\
(0.009)+\text { Capsicum } \\
\text { oleoresin }(0.006)\end{array}$ & $\begin{array}{l}\downarrow \text { Macrophages in Peyer's patches; } \\
\downarrow \text { Macrophages and } \gamma \delta+T \text { cells in } \\
\text { lymph nodes; } \downarrow \text { Lymphocyte and } \\
\text { cell density in lamina propria }\end{array}$ & {$[37]$} \\
\hline 21 & E. coli K99 & 60 & $\uparrow W e i g h t$ gain; $\uparrow$ Gain:Feed ratio & Colistin (0.3) & No differences observed & [31] \\
\hline 26 & None & 40 & $\begin{array}{l}\uparrow \text { Weight gain; } \uparrow F e e d \text { intake; } \\
\uparrow \text { Gain:Feed ratio }\end{array}$ & Avilamycine (0.04) & $\begin{array}{l}\text { } \text { Weight gain; } \uparrow F e e d \text { intake; } \\
\uparrow \text { Gain:Feed ratio }\end{array}$ & [29] \\
\hline 21 & E. coli K88 & 60 & $\begin{array}{l}\uparrow \text { Feed intake; } \uparrow \text { Weight gain; } \\
\downarrow \text { Specific K88 IgA; } \uparrow \text { Crypt depth; } \\
\downarrow \text { LL-8; } \downarrow \text { TNF-a }\end{array}$ & $\begin{array}{l}\text { Colistin }(0.25)+ \\
\text { Amoxycycline (0.5) }\end{array}$ & $\begin{array}{l}\uparrow F e e d \text { intake; } \uparrow \text { Weight gain; } \\
\uparrow C r y p t \text { depth; } \downarrow \text { IL-8; } \downarrow \text { TNF-a; } \\
\downarrow \text { IFN- } \gamma\end{array}$ & {$[23]$} \\
\hline \multirow[t]{2}{*}{10} & \multirow[t]{2}{*}{ E. coli K88 } & 50 & $\begin{array}{l}\uparrow \text { Weight gain; } \downarrow \text { Scours; } \downarrow \text { Mortality; } \\
\uparrow \text { Villi height }\end{array}$ & \multirow[t]{2}{*}{$\begin{array}{l}\text { E. coli K88 specific egg } \\
\text { yolk antibodies ( } 5 \text { ) }\end{array}$} & $\downarrow$ Villi height & \multirow[t]{2}{*}[35]{} \\
\hline & & 100 & $\begin{array}{l}\uparrow \text { Weight gain; } \downarrow \text { Scours; } \downarrow \text { Mortality; } \\
\uparrow \text { Villi height; } \downarrow \text { Plasma urea N }\end{array}$ & & $\downarrow$ Mortality; $\downarrow$ Villi height & \\
\hline \multirow[t]{4}{*}{10} & \multirow[t]{4}{*}{ E. coli K88 } & \multirow[t]{4}{*}{100} & \multirow{4}{*}{$\begin{array}{l}\downarrow \text { Plasma urea N; } \downarrow \text { Scours; } \\
\downarrow \text { Mortality; } \downarrow \text { E. coli K88 shedding; } \\
\uparrow \text { Villi height; } \uparrow \text { Villi:Crypt ratio }\end{array}$} & Carbadox (0.055) & No differences observed & \multirow[t]{4}{*}{ [33] } \\
\hline & & & & $\begin{array}{l}\text { E. coli K88 specific egg } \\
\text { yolk antibodies (5) }\end{array}$ & No differences observed & \\
\hline & & & & Zinc oxide (2.88) & 个Villi height; $\uparrow$ Villi:Crypt ratio & \\
\hline & & & & Fumaric acid (0.02) & No differences observed & \\
\hline 24 & E. coli K99 & 70 & $\begin{array}{l}\uparrow \text { Weight gain; } \uparrow \text { Gain:Feed ratio; } \\
\uparrow \text { Lactobacilli }\end{array}$ & Colistin (0.3) & $\uparrow$ E. coli & {$[28]$} \\
\hline 21 & None & 50 & $\uparrow$ Weight gain; $\uparrow$ Gain:Feed ratio & Colistin (0.15) & No differences observed & [11] \\
\hline $22 \& 32$ & None & 50 & $\uparrow$ Gain:Feed ratio & Colistin (0.15) & No differences observed & {$[11]$} \\
\hline 30 & None & 50 & $\uparrow$ Weight gain; $\uparrow F e e d$ intake & $\begin{array}{l}\text { Chlortetracycline }(0.11)+ \\
\text { Sulfamethazine }(0.11)+ \\
\text { Penicillin }(0.055)+ \\
\text { Copper sulfate }(0.25)\end{array}$ & No differences observed & {$[12]$} \\
\hline
\end{tabular}

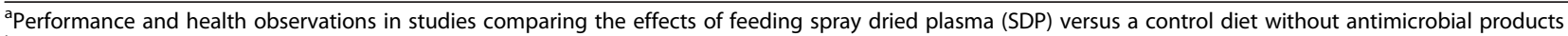
${ }^{b}$ Performance and health observations in studies comparing the effects of feeding spray dried plasma (SDP) versus the use of antibiotics or other alternative substances

[46]. The effects of SDP supplementation in reducing a toxin-induced increase in mucosal permeability may prevent the passage of microbial and food antigens into the interstitial space, thereby blocking local inflammation [47].

These effects of SDP supplementation improving intestinal tightness were observed not only during intestinal inflammation, but also in non-inflamed pigs [48]. This effect of SDP could be mediated by increased enterocyte proliferation, as shown in vitro experiments performed by Tran et al. [49]. On the other hand, SDP also modified the intestinal morphology, since supplemented pigs showed higher villous height and reduced cellularity, which was associated to lower immune activation [37]. In this line, Maijó et al. [50] demonstrated that SDP increased IL-10 production in intestinal mucosa of non-inflamed mice, which can reduce basal immune system activation. 
The intestinal surface is exposed to a great variety of pathogens but also to non-pathogenic antigens. Intestinal mucosa is protected by gut-associated lymphoid tissue (GALT), which primary role is to recognize, destroy, and eliminate pathogens but must not respond to nonpathogenic antigens. However, if the immune system is stimulated and the response is not controlled, this can lead to tissue damage [51]. In this sense, the mechanism of action of SDP on pig performance involves regulation of GALT. It must be considered that SDP contains growth factors, cytokines and other biologically active compounds that may also contribute to its positive effects on pig performance [19]. These proteins can interact with immune cells present in the mucosa thus changing the cytokine environment. Bosi et al. [23] observed a reduction in the production of the pro-inflammatory cytokines (TNF- $\alpha$, IL-8 and IFN- $\gamma$ ) in the jejunum of SDP-fed piglets challenged with enterotoxigenic E. coli K88. Furthermore, SDP reduced the SEB induced activation of T-helper cells in a rat model of acute intestinal inflammation [52, 53] (Fig. 2). T-helper lymphocyte activation produces a cytokine release that amplifies the immune response and inflammation [54]. These effects on the mucosal cytokine profile can explain the observed reductions in mucosal inflammation by SDP and the preventive effects of SDP on mucosal permeability and tight junction protein expression [46]. The effects of SDP on GALT are mediated by changes in the ratio between immune activation and immune tolerance $[55,56]$. In particular, in SEB challenged rat undergoing mild intestinal inflammation, SDP reduced the production of mucosal pro-inflammatory cytokines and increased production of anti-inflammatory cytokine IL-10 [55], and in mice genetically modified to develop colitis spontaneously, SDP promoted the $\mathrm{T}$ regulatory lymphocytes [56]. This supports the hypotheses that SDP reduces over-stimulation of the mucosal immune response by enhancing IL-10 secretion and therefore, allowing more of the available energy and nutrients to be used for growth and other productive functions rather than being diverted to support the immune response.

In addition to this intestinal effect, SDP also modified the immune response on other mucosal areas. For example, feeding SDP to weaned pigs challenged with swine influenza virus reduced lung lesions compared with a non-supplemented diet [25] and prevented the increased activated lymphocyte populations in a LPS induced lung inflammation [50]. Moreover, SDP supplementation also decreased the uterine concentrations of TNF- $\alpha$ and IFN- $\gamma$, and increased the concentration of TGF- $\beta 1$ [57]. Therefore, the beneficial effects of SDP not only occur locally at the gut level, but also occur at a systemic level. Since organized GALT is an inductive site that connects with both local and peripheral effector sites (respiratory tracts, glandular tissues and the uterus mucosa), it can be further hypothesized that SDP may reduce over stimulation of the broader common mucosal immune system (Fig. 3).

\section{Biosafety of spray dried plasma of porcine origin}

Spray dried plasma of porcine origin (SDPP) is a feed ingredient derived from the blood of pigs, and is a product whose biosafety is often under scrutiny, particularly during periods of emergence or re-emergence of swine diseases in different regions of the world. In response to these concerns, a significant amount of literature has become available to evaluate the safety of commercial SDPP about a variety of bacteria and viruses affecting the swine industry. These publications indicated several aspects in the manufacturing process of commercial SDPP that contribute to the bio-safety of this functional protein ingredient, starting with the fact that only blood from healthy pigs determined as fit for slaughter for human consumption is collected for commercially produced SDPP. This is the first critical
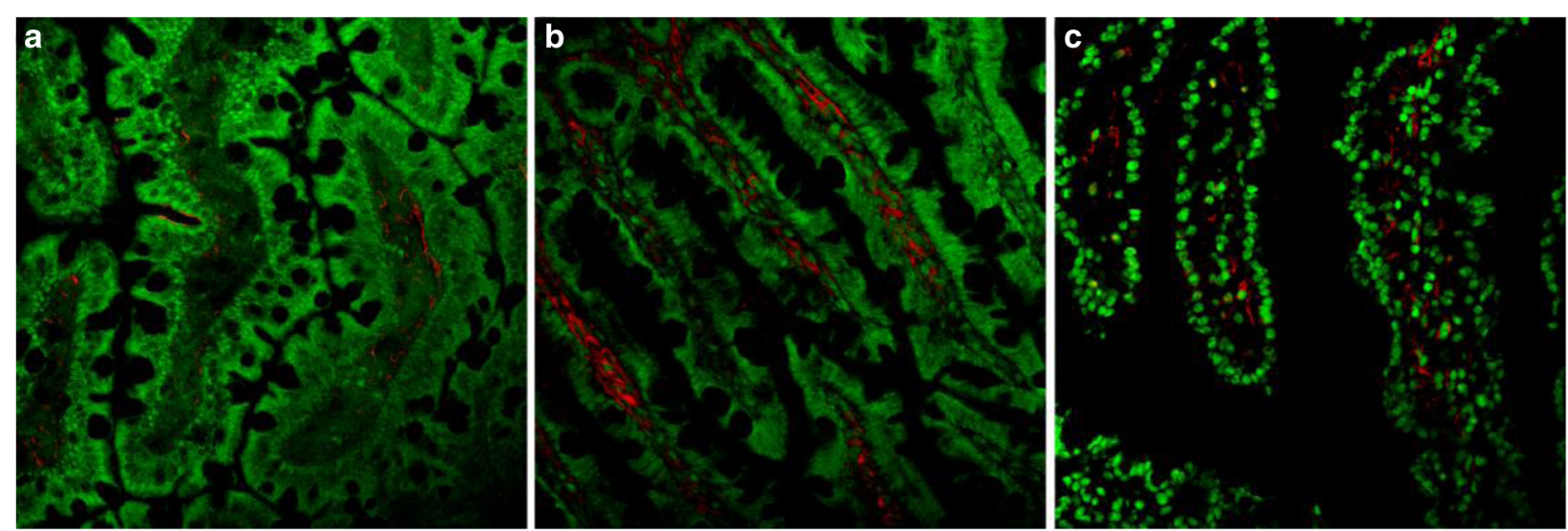

Fig. 2 Representative images of the immunohistocheminal localization of activated lymphocytes in the jejunum of the Control (a), SEB (b) and SEB-SDP (c) rats. Jejunum mucosa sections were immunostained with anti-IL-2R (anti-CD25) and counterstained with Hoechst 33258 (nuclear marker). Staining for lymphocyte markers is shown in red and nuclei in green 


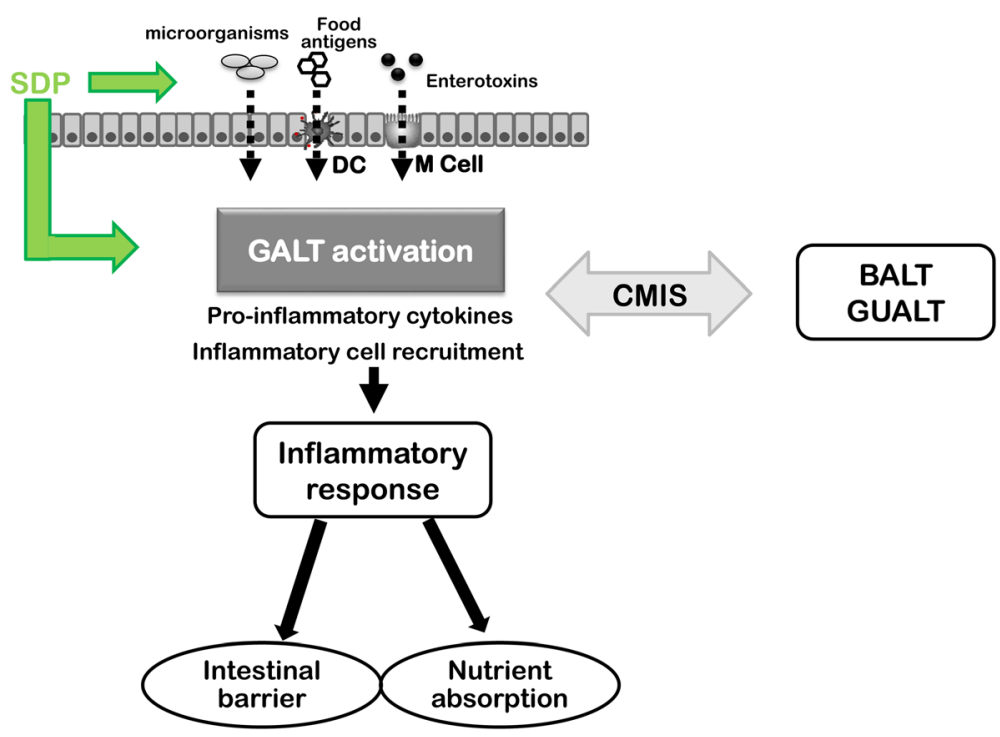

Fig. 3 Diagram summarizing the mode of action of spray-dried plasma (SDP). Food antigens and products from commensal bacteria can enter into the intestinal lamina propria across M cells (in Peyer's patches), by dendritic cells (DC), or by paracellular pathway. This results in activation of the Gut-Associated Lymphoid Tissue (GALT), which induces an inflammatory response that can alter different intestinal functions such as intestinal barrier or nutrient absorption. GALT is interconnected to other mucosal surfaces like the Broncoalveolar-Associated Lymphoid Tissue (BALT) or the Genito Urinary-Associated Lymphoid Tissue (GUALT) by the common mucosal immune system (CMIS). Plasma supplementation can modulate the immune response at the luminal level (e.g.: modifying the microbiota profile, reducing antigen and pathogen concentration by luminal binding). Moreover, biologically active compounds present in plasma supplements can also interact directly with mucosal immune cells. The plasma-induced changes in mucosal cytokine profile can prevent or reverse deleterious effects resulting from immune system activation

control point in the manufacturing process of SDPP. Avoidance of collecting plasma from clinically affected pigs decreases the risk of potential pathogen transmission; however, in case of asymptomatic diseases, the safety features of the whole manufacturing process should assure inactivation of such pathogens that cannot be detected at inspection. The general procedures involve collection of pooled blood at inspected abattoirs, transport to remote processing plants, drying, and packaging of the dried product. Liquid pooled plasma used in commercial production of SDPP inherently contains antibodies with neutralizing capacity against a variety of pathogens, which contributes to the biosafety of the finished product and this is an additional critical control point in the process of manufacturing SDPP [58].

The spray-drying process has demonstrated its efficacy as a pasteurization-like process to eliminate bacteria and viruses [59]. During spray drying, it is ensured that plasma is exposed to temperatures over $80^{\circ} \mathrm{C}$ throughout its substance and this is one of the most important critical control point in the manufacturing process of SDPP (Fig. 1).

Research, in which plasma has been inoculated with different viruses prior to drying, has shown that spray drying is an effective method to inactivate Pseudorabies virus, Porcine Reproductive and Respiratory Syndrome virus (PRRSV) [60], and Swine Vesicular Disease virus [61]. Animal studies have also failed to show any evidence of transmission of Porcine Circovirus type 2
(PCV2) [59, 62-64] when diets supplemented with commercial SDPP containing the genome of this virus were fed to pigs, even though these particular virus is considered to be amongst the most heat stable swine viruses known today [65]. However, other authors [66] reported PCV2 transmission in naïve pigs given an oral gavage of experimentally produced SDPP. The experimental SDPP used in this study was produced using a laboratory scale spray-dryer from the blood of a single infected pig showing PCV2 viremia without PCV2 neutralizing antibodies and clinical evidence of post-weaning multisystemic wasting syndrome. Several variables influenced these results, including high virus load (the plasma was obtained from a single pig at peak viremia), the use of low inlet $\left(166{ }^{\circ} \mathrm{C}\right)$ and outlet temperatures $\left(67-71{ }^{\circ} \mathrm{C}\right)$, small particle size $(10 \mu \mathrm{m})$, and less than $1 \mathrm{sec}$ residence time which is lower than those typical for industrial dryers (inlet temperature, $170-310{ }^{\circ} \mathrm{C}$; outlet temperature, 80-90 ${ }^{\circ} \mathrm{C}$; particle size, $45-150 \mu \mathrm{m}$; residence time, 20 $90 \mathrm{sec})$. Moreover, as stated before, commercial SDPP is always obtained from healthy pigs determined as fit for slaughter for human consumption. The differences in source material and manufacturing processes may explain the contradicting results obtained between the study conducted by Patterson et al. [66] and other studies $[37,59,62-64]$ that used commercially produced SDPP, even though PCV2 DNA was present in the tested commercial SDPP. 
In addition, it also has been demonstrated throughout retrospective feeding studies that the manufacturing process of SDPP inactivated Hepatitis E virus [67], another virus of concern in the swine industry.

With the emergence of Porcine Epidemic Diarrhea virus (PEDV) in North America, feed containing SDPP was suspected to play a role in the spread of PEDV [68]. However, there is evidence indicating that the spray drying process, even at lower temperatures than those used to produce commercial SDPP, inactivate PEDV $[69,70]$. In addition, it has also been reported that PEDV inoculated in SDPP survived for less than 7 days when stored at room temperature (20-22 $\left.{ }^{\circ} \mathrm{C}\right)$ [69]. Similarly, other research has shown that PEDV does not survive in swine feces for more than 7 days when stored at room temperature [71]. In a recent publication [72], PEDV was inoculated in several ingredients commonly used in swine diets and stored outdoors under winter time ambient conditions of Minnesota. Samples were tested for viable PEDV using virus isolation or swine bioassay at different storage days post-inoculation (DPI). Results showed that PEDV inoculated on soybean meal remained infectious for 180 DPI, while PEDV inoculated on SDPP was not infective by swine bioassay just after 1 DPI. This study demonstrated that PEDV viability in feed appears to be influenced by ingredient type, with extended survival reported in soybean meal, and therefore pointed out a potential way of PEDV introduction in North America. Furthermore, the results confirmed that SDPP was not an ingredient where PEDV can survive for a long period of time. In addition, two studies demonstrated that feeding diets containing SDPP with the PEDV genome did not cause transmission of the disease to PEDV-naïve pigs even when fed at $5 \%$ of the diet for either 14 [73] or 28 days [74]. Moreover, additional swine bioassays conducted with different lots of SDPP PCR positive for PEDV genome demonstrated lack of infectivity [75]. Even more, an epidemiological investigation of porcine origin feed ingredients and the occurrence of PEDV at Midwestern USA swine farms concluded that SDPP and porcine-origin feed ingredients in general, had negligible to very low association with PEDV in pigs consuming that feed [76]. Finally, it has been reported that millions of pigs in PEDV free regions remained free of PEDV even though these pig populations had been fed PEDV PCR positive SDPP [77].

The fact that only one published study [68] had associated the first cases of PEDV infection in Ontario Canada with feed containing SDPP that was PCR positive for PEDV is controversial because the origin of the infectious PEDV in that study was not clear [78]. In that paper, a bioassay reported that the SDPP used in the feed was infectious; however, the feed containing the SDPP was not infectious. Also the SDPP used in that study was manufactured more than two months earlier than the initial PEDV cases were reported [79]. As indicated in previous studies,
PEDV was unable to survive spray-drying conditions typical for commercial SDPP and PEDV did not survive in SDPP samples kept in refrigerated storage for more than 2 to 3 weeks. These data suggest that the first PEDV cases reported in Canada were a consequence of cross-contamination of the SDPP product with other infective sources.

Collectively the results of these studies provide solid evidence to support the fact that commercial SDPP is a safe product for pigs, even though the genome of various swine pathogens may be present in SDPP.

Furthermore, SDPP is a dry product with low moisture $(<9 \%)$ and very low water activity (Aw <0.6). Some pathogens, especially enveloped viruses such as PRRSV, transmissible gastroenteritis virus or PEDV are not able to survive for a prolonged period in dry materials like SDPP. Therefore, as an additional safety feature, the members of the North American Spray Dried Blood \& Plasma Producers Association (NASDBPP) and the European Animal Protein Association (EAPA), which represent approximately $65-70 \%$ of the spray-dried blood products produced worldwide, voluntarily stores SDP products of porcine origin at room temperature $\left(>20{ }^{\circ} \mathrm{C}\right)$ for two weeks after packaging as additional safety feature to assure customers inactivation of any potential post-processing contamination of pathogens on packaged product.

In addition, a worldwide leader spray dried plasma producer has recently introduced a new technology based on ultraviolet (UV) irradiation of liquid plasma before concentration and spray-drying that will be considered as a redundant safety step. UV irradiation of liquid plasma has demonstrated to no affect functionality of SDPP when supplemented in post-weaning diets and UV irradiation is a recognized technology able to inactivate a variety of pathogen including a diversity of bacteria and viruses, including porcine parvovirus, a model virus of very high heat and chemical resistant virus [80].

\section{Conclusions}

There is clear evidence supporting SDP as an effective alternative to antibiotics for piglets, particularly during the first weeks post-weaning. In general, SDP had better or equivalent efficacy on pig performance compared with antibiotics or other alternative antimicrobial products. The efficacy of SDP in animal feed appears to be related mainly to an improved barrier function of the gut mucosa and the modulation of the mucosal immune response. The additive responses observed when SDP is offered in combination with antibiotics or other alternative products, suggest differences in their modes of action and this is an area that deserves further research. The available biosafety studies provide enough evidence to support that commercial SDPP is a safe product for pigs. 


\section{Abbreviations}

DPI, days post-infection; GALT, gut-associated lymphoid tissue; PCV2, Porcine Circovirus type 2; PEDV, porcine epidemic diarrhea virus; PRRSV, porcine reproductive and respiratory syndrome virus; SDP, spray dried plasma (general term for spray dried plasma independently of its source origin: porcine, bovine or mix); SDPP, spray dried porcine plasma; SEB, S. aureus enterotoxin B

\section{Authors' contributions}

DT, JP and APB co-wrote this review. All authors read and approved the final version of the manuscript for publication.

\section{Competing interests}

DT and APB declare they have no competing interest. JP is employed at APC Europe, S.A.

\section{Author details}

${ }^{1}$ Grup de Fisiologia digestiva i adaptacions nutricionals, Departament de Bioquímica i Fisiologia, Facultat de Farmàcia i Ciències de l'Alimentació, Institut de Recerca en Nutrició i Seguretat Alimentària, Universitat de Barcelona (UB), Barcelona, Spain. ${ }^{2}$ APC Europe, S.A., Granollers, Spain. ${ }^{3}$ IRTA, Animal Nutrition and Welfare, Mas de Bover, Ctra. Reus-El Morell, km. 3.8, E-43120 Constantí, Tarragona, Spain.

Received: 30 March 2016 Accepted: 3 June 2016

\section{Published online: 23 July 2016}

\section{References}

1. Gatnau R, Paul PS, Zimmerman DR. Spray dried porcine plasma as a source of immunoglobulins for newborn piglets. J Anim Sci. 1989;67 Suppl 1:244.

2. Borg BS, Campbell JM, Russell LE, Rodríguez C, Ródenas J. Evaluation of the chemical and biological characteristics of spray-dried plasma protein collected from various locations around the world. Am Assoc Swine Vet. 2002;33:97-100.

3. Zimmerman DR. Porcine plasma proteins in diets of weanling pigs. Swine Research Reports. Ames, lowa: lowa State University; 1987.

4. Gatnau R, Zimmerman DR. Spray dried porcine plasma (SDPP) as a source of protein for weanling pigs. J Anim Sci. 1990;68 Suppl 1:374.

5. Coffey MT, Cromwell GL. Use of spray-dried animal plasma in diets for weanling pigs. Pigs News Information. 2001;22:39-48.

6. van Dijk AJ, Everts H, Nabuurs MJA, Margry R, Beynen AC. Growth performance of weanling pigs fed spray-dried animal plasma: a review. Livest Prod Sci. 2001;68:263-74.

7. Torrallardona D. Spray dried animal plasma as an alternative to antibiotics in weanling pigs-A review. Asian-Aust J Anim Sci. 2010;23:131-48.

8. Gatnau R, Zimmerman DR. Spray dried porcine plasma (SDPP) as a source of protein for weanling pigs in two environments. J Anim Sci. 1991;69 Suppl 1:103.

9. van der Peet Schwering CMC, Binnendijk GP. The effect of spray-dried porcine plasma in diets with different protein sources on the performance of weanling piglets. Proefverslag Proefstation voor de Varkenshouderij. 1995;1:137.

10. Cain CM, Zimmerman DR. Effect of spray dried plasma (SDP) on fecal shedding of hemolytic Escherichia coli (HEC) and rotavirus by pigs in a segregated early-weaned (SEW) environment. J Anim Sci. 1997:75 Suppl 1:61.

11. Torrallardona D, Conde R, Esteve-Garcia E, Brufau J. Use of spray dried animal plasma as an alternative to antimicrobial medication in weanling pigs. Anim Feed Sci Technol. 2002;99:119-29.

12. Coffey RD, Cromwell GL. The impact of environment and antimicrobia agents on the growth response of early-weaned pigs to spray-dried porcine plasma. J Anim Sci. 1995:73:2532-9.

13. Bergstrom JR, Nelssen JL, Tokach MD, Goodband RD, Dritz SS, Owen KQ, et al. Evaluation of spray-dried animal plasma and select menhaden fish meal in transition diets of pigs weaned at 12 to 14 days of age and reared in different production systems. J Anim Sci. 1997;75:3004-9.

14. Pierce $J$, Cromwell GL, Lindemann MD, Russell LE, Weaver EM. Effects of spray-dried animal plasma and immunoglobulins on performance of early weaned pigs. J Anim Sci. 2005;83:2876-85.

15. Svendsen J, Larsen JL. Studies of the pathogenesis of enteric E. coli infections in weaned pigs. The significance of the milk of the dam in preventing the disease. Nord Vet Med. 1977;29:533-8.
16. Svendsen J, Brown P. IgA immunoglobulin levels in porcine sera and mammary secretions. Res Vet Sci. 1973;15:65-9.

17. Hunziker W, Kraehenbuhl JP. Epithelial transcytosis of immunoglobulins. J Mammary Gland Biol Neoplasia. 1998:3:287-302.

18. Monks J, Neville MC. Albumin transcytosis across the epithelium of the lactating mouse mammary gland. J Physiol Lond. 2004;560:267-80.

19. Lallès JP, Bosi P, Janczyk P, Koopmans SJ, Torrallardona D. Impact of bioactive substances on the gastrointestinal tract and performance of weaned piglets: A review. Animal. 2009;3:1625-43.

20. Dewey CE, Johnston WT, Gould L, Whiting TL. Post-weaning mortality in Manitoba swine. Can J Vet Res. 2006;70:161-7.

21. Roura E, Homedes J, Klasing KC. Prevention of immunologic stress contributes to the growth-permitting ability of dietary antibiotics in chicks. J Nutr. 1992;122:2383-90.

22. Rojas JL, Jurgens MH, Zimmerman DR. Effect of spray-dried porcine plasma, antimicrobial agents or their combination on performance of weanling pigs. Swine Research Report. Ames, IA: lowa State University; 1994. p. AS-629.

23. Bosi P, Casini L, Finamore A, Cremokolini C, Merialdi G, Trevisi P, et al. Spraydried plasma improves growth performance and reduces inflammatory status of weaned pigs challenged with enterotoxigenic Escherichia coli K88. J Anim Sci. 2004;82:1764-72.

24. Messier S, Gagne-Fortin C, Crenshaw J. Dietary spray-dried porcine plasma reduces mortality attributed to porcine circovirus associated disease syndrome. In: Proc Amer Assoc Swine Vet. 2007. p. 147-50.

25. Campbell J, Crenshaw J, Polo J. Impact of feeding spray-dried plasma to pigs challenged with swine influenza virus. Barcelona, Spain: Proceedings of the International Symposium on Emerging and Re-emerging Pig Diseases; 2011. p. 12-5. 2011:269.

26. Eastwood L, Shea J, Gillis D, Beaulieu D. Spray-dried animal plasma mitigates the negative impact of deoxynivalenol (DON) in nursery pigs. J Anim Sci. 2013:91 Suppl 2:32.

27. Weaver AC, Campbell JM, Crenshaw JD, Polo J, Kim SW. Efficacy of dietary spray dried plasma protein to mitigate the negative effects on performance of pigs fed diets with corn naturally contaminated with multiple mycotoxins. J Anim Sci. 2014:92:3878-86.

28. Torrallardona D, Conde MR, Badiola I, Polo J, Brufau J. Effect of fishmeal replacement with spray-dried animal plasma and colistin on intestinal structure, intestinal microbiology, and performance of weanling pigs challenged with Escherichia coli K99. J Anim Sci. 2003;81:1220-26.

29. Bikker P, van Dijk AJ, Dirkzwager A, Fledderus J, Ubbink-Blanksma M, Beynen AC. The influence of diet composition and an anti-microbial growth promoter on the growth response of weaned piglets to spray dried animal plasma. Livest Prod Sci. 2004;86:201-8.

30. Torrallardona D, Conde R, Badiola JI, Polo J. Evaluation of spray dried animal plasma and calcium formate as alternatives to colistin in piglets experimentally infected with Escherichia coli K99. Livest Sci. 2007;108:303-6.

31. Conde R. SDAP in piglet nutrition. A possible alternative to antibiotics. Bellaterra, Spain: PhD Thesis, Autonomous University of Barcelona; 2005.

32. Polo J, Deike V, Revy PS, Le Nezet JY, Crenshaw J. Study of the use of porcine plasma as an alternative to medicated feed in piglet weaning diets. Journées Recherche Porcine. 2014;46:93-4.

33. Owusu-Asiedu A, Nyachoti CM, Marquardt RR. Response of early-weaned pigs to an enterotoxigenic Escherichia coli (K88) challenge when fed diets containing spray-dried porcine plasma or pea protein isolate plus egg yolk antibody, zinc oxide, fumaric acid, or antibiotic. J Anim Sci. 2003:81:1790-8

34. Owusu-Asiedu A, Baidoo SK, Nyachoti CM, Marquardt RR. Response of early-weaned pigs to spray-dried porcine or animal plasma-based diets supplemented with egg-yolk antibodies against enterotoxigenic Escherichia coli. J Anim Sci. 2002;80:2895-903.

35. Owusu-Asiedu A, Nyachoti CM, Baidoo SK, Marquardt RR, Yang X. Response of early-weaned pigs to an enterotoxigenic Escherichia coli (K88) challenge when fed diets containing spray-dried porcine plasma or pea protein isolate plus egg yolk antibody. J Anim Sci. 2003;81:1781-9.

36. Torrallardona D, Polo J. Effect of spray-dried porcine plasma protein and egg antibodies in diets for weaned pigs under environmental challenge conditions. J Swine Health Prod. 2016:24:21-8.

37. Nofrarías M, Manzanilla EG, Pujols J, Gibert X, Majó N, Segalés J, et al. Effects of spray-dried porcine plasma and plant extracts on intestinal morphology and on leukocyte cell subsets of weaned pigs. J Anim Sci. 2006;84:2735-42. 
38. Zhao J, Harper AF, Estiennev MJ, Webb Jr KE, McElroy AP, Denbow DM. Growth performance and intestinal morphology responses in early weaned pigs to supplementation of antibiotic free diets with an organic copper complex and spray-dried plasma protein in sanitary and non-sanitary environments. J Anim Sci. 2007;85:1302-10.

39. Srichana P, Gaines AM, Ratliff BW, Allee GL, Crenshaw JD, Campbell JM, et al. Impact of spray-dried plasma with or without antimicrobials on nursery pig performance. J Anim Sci. 2004;82 Suppl 1:140.

40. Blikslager AT. Mucosal epithelial barrier repair to maintain pig health. Livest Sci. 2010;133:194-9.

41. Toivola DM, Krishnan S, Binder HJ, Singh SK, Omary MB. Keratins modulate colonocyte electrolyte transport via protein mis-targeting. J Cell Biol. 2004;164:911-21.

42. Bruewer M, Luegering A, Kucharzik T, Parkos CA, Madara JL, Hopkins AM, et al. Pro-inflammatory cytokines disrupt epithelial barrier function by apoptosis-independent mechanisms. J Immunol. 2003;171:6164-72.

43. Tsukita S, Furuse M, Itoh M. The tight junction. In: Berkeley MC, editor Cell adhesion. New York: Oxford University Press; 2002. p. 369-95.

44. Corl BA, Harrell RJ, Moon HK, Phillips O, Weaver EM, Campbell JM, et al. Effect of animal plasma proteins on intestinal damage and recovery of neonatal pigs infected with rotavirus. J Nutr Biochem. 2007:18:778-84

45. Arthington JD, Jaynes CA, Tyler HD, Kapil S, Quigley III JD. The use of bovine serum protein as an oral support therapy following coronavirus challenge in calves. J Dairy Sci. 2002;85:1249-54

46. Pérez-Bosque A, Amat C, Polo J, Campbell JM, Crenshaw J, Russell L, et al. Spray-dried animal plasma prevents the effects of Staphylococcus aureus Enterotoxin B on intestinal barrier function in weaned rats. J Nutr. 2006;136:2838-43.

47. Santos J, Yang PC, Soderholm JD, Benjamin M, Perdue MH. Role of mast cells in chronic stress induced colonic epithelial barrier dysfunction in the rat. Gut. 2001;48:630-6.

48. Peace RM, Campbell J, Polo J, Crenshaw J, Russell L, Moeser A. Spray-dried porcine plasma influences intestinal barrier function, inflammation, and diarrhea in weaned pigs. J Nutr. 2011;141(7):1312-7. doi:10.3945/jn.110. 136796.

49. Tran H, Bundy JW, Li YS, Carney-Hinkle EE, Miller PS, Burkey TE. Effects of spray-dried porcine plasma on growth performance, immune response, total antioxidant capacity, and gut morphology of nursery pigs. Anim Sci. 2014;92(10):4494-504. doi:10.2527/jas.2014-7620

50. Maijó M, Miró L, Polo J, Campbell J, Russell L, Crenshaw J, et al. Dietary plasma proteins modulate the adaptive immune response in mice with acute lung inflammation. J Nutr. 2012;142:264-70.

51. McKay DM, Benjamin MA, Lu J. CD4 T cells mediate super-antigen induced abnormalities in murine jejunal ion transport. Am J Physiol. 1998; 275:G29-38.

52. Pérez-Bosque A, Pelegrí C, Vicario M, Castell M, Russell L, Campbell JM, et al. Dietary plasma protein affects the immune response of weaned rats challenged with S. aureus super-antigen B. J Nutr. 2004;134:2667-72.

53. Pérez-Bosque A, Miró L, Polo J, Russell L, Campbell J, Weaver E, et al. Dietary plasma proteins modulate the immune response of diffuse gut-associated lymphoid tissue in rats challenged with Staphylococcus aureus enterotoxin B. J Nutr. 2008;138:533-7.

54. Mowat AM. Anatomical basis of tolerance and immunity to intestinal antigens. Nat Rev Immunol. 2003;3:331-41.

55. Pérez-Bosque A, Miró L, Polo J, Russell L, Campbell J, Weaver E, et al. Dietary plasma protein supplements prevent the release of mucosal pro-inflammatory mediators in intestinal inflammation in rats. J Nutr. 2010;140:25-30

56. Moretó M, Pérez-Bosque A. Dietary plasma proteins, the intestinal immune system, and the barrier functions of the intestinal mucosa. J Anim Sci. 2009;87(14 Suppl):E92-E100.

57. Song M, Liu Y, Lee JJ, Che TM, Soares-Almeida JA, Chun JL, et al. Spraydried plasma attenuates inflammation and improves pregnancy rate of mated female mice. J Anim Sci. 2015;93:298-305.

58. Polo J, Opriessnig T, O'Neill KC, Rodríguez C, Russell LE, Campbell JM, et al. Neutralizing antibodies against porcine circovirus type 2 in liquid pooled plasma contribute to the biosafety of commercially manufactured spray-dried porcine plasma. J Anim Sci. 2013;91:2192-8.

59. Pujols J, López-Soria S, Segalés J, Fort M, Sibila M, Rosell R, et al. Lack of transmission of porcine circovirus type 2 to weanling pigs by feeding them spray-dried porcine plasma. Vet Rec. 2008;163:536-8.
60. Polo J, Quigley JD, Russell LE, Campbell JM, Pujols J, Lukert PD. Efficacy of spray-drying to reduce infectivity of pseudo rabies and porcine reproductive and respiratory syndrome (PRRS) viruses and seroconversion in pigs fed diets containing spray-dried animal plasma. J Anim Sci. 2005:83:1933-8.

61. Pujols J, Rosell R, Russell L, Campbell J, Crenshaw J, Weaver E, et al. Inactivation of swine vesicular disease virus in porcine plasma by spraydrying. Perry, IA: Proc Am Assoc Swine Vet; 2007. p. 281-3.

62. Opriessnig T, Yoon KJ, Russell L, Halbur PG. No evidence of infectivity of PCV2 nucleic acids present in spray-dried plasma protein. Lincoln, NE: Proc 45th Ann Meeting North Central Conf Vet Lab Diagnosticians; 2006. p. 14-5.

63. Pujols J, Lorca-Oró C, Díaz I, Russell LE, Campbell JM, Crenshaw JD, et al. Commercial spray-dried porcine plasma does not transmit porcine circovirus type 2 in weaned pigs challenged with porcine reproductive and respiratory syndrome virus. Vet J. 2011;190:e16-20.

64. Shen HG, Schalk S, Halbur PG, Campbell JM, Russell LE, Opriessnig T. Commercially produced spray-dried porcine plasma contains increased concentrations of porcine circovirus type 2 DNA but does not transmit porcine circovirus type 2 when fed to naive pigs. J Anim Sci. 2011;89:1930-8.

65. Opriessnig T, Shen H, Harrison S, Campbell J, Faidley T, Russell L, et al. Commercial spray-dried porcine plasma contains high amounts of PCV2 DNA and high levels of anti-PCV2 antibodies but is not infective to naive pigs. Vancouver, Canada: Proc 21st IPVS Congress; 2010. p. 338.

66. Paterson AR, Madson DM, Opriessnig T. Efficacy of experimentally-produced spray-dried plasma on infectivity of porcine circovirus type 2 (PCV2) J Anim Sci. 2010;88(12):4078-85.

67. Pujols J, Rodríguez C, Navarro N, Pina-Pedrero S, Campbell JM, Crenshaw J, et al. No transmission of hepatitis $E$ virus in pigs fed diets containing commercial spray-dried porcine plasma: a retrospective study of samples from several swine trials. Virology J. 2014;11:232. doi:10.1186/s12985-0140232-x.

68. Pasick J, Berhane Y, Ojkic D, Maxie G, Embury-Hyatt C, Swekla K, et al. Investigation into the role of potentially contaminated feed as a source of the first-detected outbreaks of porcine epidemic diarrhea in Canada. Transboundary and Emerg Dis. 2014;61(5):397-410.

69. Pujols J, Segalés J. Survivability of porcine epidemic diarrhea virus (PEDV) in bovine plasma submitted to spray drying processing and held at different time by temperature storage conditions. Vet Microbiol. 2014;174:427-32.

70. Gerber PF, Xiao C-T, Chen Q, Zhang J, Halbur PG, Opriessnig T. The spraydrying process is sufficient to inactivate infectious porcine epidemic diarrhea virus in plasma. Vet Micro. 2014;174(1-2):86-92.

71. Thomas PR, Karriker L, Ramirez A, Zhang J, Ellingson J, Holtkamp D. In: Hernández J, Zimmerman J, editors. Evaluation of time and temperature sufficient to inactivate porcine epidemic diarrhea virus in swine feces on metal surfaces. Cancun, Mexico: Proc 23rd IPVS Congress; 2014. p. 249-11.

72. Dee S, Neil C, Clement T, Singrey A, Christopher-Hennings J, Nelson E. An evaluation of porcine epidemic diarrhea virus survival in individual feed ingredients in the presence or absence of a liquid Antimicrobial. Porcine Health Management. 2015;1:9. doi:10.1186/s40813-015-0003-0.

73. Campbell JM, Crenshaw JD, Polo J, Saltzman R, Kesl L. Weaned pigs fed a diet with commercial PEDV PCR positive spray-dried porcine plasma did not develop porcine epidemic diarrhea virus (PEDV). Proc Allen D Leman Swine Conf. 2014:40:15.

74. Opriessnig T, Xiao CT, Gerber PF, Zhang J, Halbur PG. Porcine epidemic diarrhea virus RNA present in commercial spray-dried porcine plasma is not infectious to naïve pigs. Plos One. 2014;9:1-10.

75. Pillatzki AE, Gauger PC, Madson DM, Burrough ER, Zhang J, Chen Q, et al. Experimental inoculation of neonatal piglets with feed naturally contaminated with porcine epidemic diarrhea virus. J Swine Health Prod. 2015:23(6):317-20

76. Neumann EJ, Ackerman MA, Troxel C, Moser RL. An epidemiological investigation of porcine origin feed ingredients and the occurrence of porcine epidemic diarrhea on Midwestern United States pork farms. 2015. p. 162. Proc Midwest American Society of Animal Science.

77. Crenshaw JD, Campbell JM, Polo J. Analysis of spray dried porcine plasma (SDPP) produced in Brazil and Western Canada confirm negative porcine epidemic diarrhea virus (PEDV) status of pigs in these regions. Proc Allen D Leman Swine Conf. 2014:40:14

78. European Food Safety Authority (EFSA). Scientific Opinion on porcine epidemic diarrhoea and emerging porcine deltacoronavirus. EFSA J. 2014;12(10):3877. 
79. NASDBPP. Studies point to plasma as safe feed ingredient. Feedstuffs. 2014;86(28):10-11,16

80. Polo J, Rodríguez C, Ródenas J, Russell LE, Campbell JM, Crenshaw JD, et al. Ultraviolet light (UV) inactivation of porcine parvovirus in liquid plasma and effect of UV irradiated spray dried porcine plasma on performance of weaned pigs. Plos One. 2015;10(7):e0133008. doi:10.1371/journal.pone. 0133008.

Submit your next manuscript to BioMed Central and we will help you at every step:

- We accept pre-submission inquiries

- Our selector tool helps you to find the most relevant journal

- We provide round the clock customer support

- Convenient online submission

- Thorough peer review

- Inclusion in PubMed and all major indexing services

- Maximum visibility for your research

Submit your manuscript at www.biomedcentral.com/submit
Biomed Central 